\title{
Hygiene Sanitasi dan Perilaku Penjamah Makanan dengan Angka Kuman pada Makanan Jajanan di Lingkungan Sekolah
}

\section{Sanitation Hygiene and Behavior of Food Handlers with Germs in Snack Food in School Environment}

Sri Indra Trigunarso

Jurusan Kesehatan Lingkungan, Politeknik Kesehatan Tanjungkarang, Indonesia

\section{ARTICLE INFO}

\section{Article history:}

Received date

27 Feb 2020

Revised date

13 Apr 2020

Accepted date

23 May 2020

Keywords:

Germ numbers;

Sanitation hygiene;

Snack food;

Touching behavior.

\section{Kata kunci:}

Angka kuman;

Hygiene sanitasi;

Makanan jajanan;

Perilaku penjamah.

\author{
ABSTRACT/ ABSTRAK
}

One of the community services in the field of food, is hawker food whose existence is often still far from meeting health requirements so that the impact of the disease on the community. By seeing the potential of such large food and high levels of vulnerability, efforts should be made to monitor the quality of food management by observing hygiene and sanitation rules and health requirements. The purpose of this study was to determine the relationship between sanitation hygiene and behavior of the handlers with the number of germs on snacks in the surroundings of the Kartika Jaya Foundation School in Bandar Lampung City. This type of research is analytic descriptive, with the cross-sectional approach. The population in this study is all traders and food sold in the environment around the school both inside and outside the school building. Samples were taken based on the determination of the sample criteria of traders and food, totaling 53 traders. The method used is a laboratory test on the number of germs on food samples and hand-held swabs by the ALT (Total Plate Number) method as well as questionnaires and observations. Data analysis was performed univariately and bivariate (using the chi-square test $\alpha=0,05$ ). From the results of this study it can be concluded that there is a relationship between sanitation hygiene $(\rho$-value $=0,0001)$ and food handler behavior $(\rho$-value $=0,004)$ with the number of germs on snacks in the surroundings of the Kartika Jaya Foundation School in Bandar Lampung City.
Salah satu jasa pelayanan masyarakat dibidang makanan, adalah makanan jajanan yang keberadaannya sering kali masih jauh dari memenuhi persyaratan kesehatan sehingga menimbulkan dampak penyakit kepada masyarakat. Melihat potensi makanan jajanan yang demikian besar dan tingkat kerawanan yang cukup tinggi perlu diupayakan pengawasan kualitas pengelolaan makanan jajanan dengan memperhatikan kaidah-kaidah kebersihan hygiene dan sanitasi serta persyaratan kesehatan. Tujuan penelitian untuk mengukur hubungan hygiene sanitasi dan perilaku penjamah dengan angka kuman pada makanan jajanan di lingkungan sekolah Yayasan Kartika Jaya Kota Bandar Lampung. Jenis penelitian ini adalah deskriptif analitik, dengan pendekatan cross sectional. Populasi pada penelitian ini adalah seluruh pedagang dan makanan yang dijual di lingkungan sekitar sekolah baik didalam maupun diluar gedung sekolah. Sampel diambil berdasarkan penentuan kriteria sampel pedagang dan makanan yang berjumlah 53 pedagang. Metode yang digunakan adalah uji laboratorium terhadap angka kuman pada sampel makanan dan tangan penjamah dengan metode ALT (Angka Lempeng Total) serta kuisioner dan observasi. Analisis data dilakukan secara univariat dan bivariat (menggunakan uji chi square $\alpha=0,05$ ). Hasil penelitian ini dapat disimpulkan bahwa terdapat hubungan antara hygiene sanitasi $(\rho$-value $=0,0001)$ dan perilaku penjamah makanan $(\rho$ value $=0,004)$ dengan angka kuman pada makanan jajanan di lingkungan Sekolah Yayasan Kartika Jaya Kota Bandar Lampung.

\section{Corresponding Author:}




\section{PENDAHULUAN}

Di lingkungan sekitar sekolah banyak sekali dijumpai makanan jajanan baik yang disediakan oleh kantin sekolah maupun pedagang kaki lima dan umumnya rutin dikonsumsi oleh sebagian anak usia sekolah. Hal ini perlu menjadi perhatian masyarakat, khususnya orang tua, pendidik, dan pengelola sekolah. Makanan jajanan sangat beresiko terhadap cemaran biologis atau kimiawi yang banyak menganggu kesehatan, baik jangka pendek maupun jangka panjang (Februhartanty dan Rimbawan, 2004). Makanan jajanan menyumbang asupan energi bagi anak sebanyak $36 \%$, protein $29 \%$, dan besi $52 \%$. Karena itu dapat dipahami peran penting makanan jajanan pada pertumbuhan dan prestasi belajar anak sekolah.

Kontaminan pada makanan berupa virus, bakteri, jamur, parasit, dan bahan kimia berbahaya. Makanan tak aman menimbulkan berbagai jenis penyakit, mulai dari diare hingga kanker. Sebagai gambaran, berdasarkan Foodborne Disease Burden Epidemiology Reference Group (FERG) 2010 dari WHO, diperkirakan 582 juta kasus muncul dari 22 penyakit yang menyebar melalui makanan (Foodborne Disease). Dan sebanyak 351.000 diantaranya berujung kematian (World Health Organization, 2015).

Di Indonesia penyakit akibat makanan masih menjadi masalah kesehatan masyarakat, berdasarkan data Badan POM (2010) dalam kurun waktu 2001-2009, terjadi 1.101 Kejadian Luar Biasa (KLB) keracunan pangan. Angka kejadian umumnya meningkat dari tahun ke tahun, penyebab keracunan makanan terdiri dari agen mikroba dan kimia. KLB keracunan pangan tertinggi terjadi pada tahun 2008, yaitu sebanyak 197 kejadian. Sekitar 26\% dari kasus ini terjadi di sekolah/kampus, $57 \%$ terjadi di rumah/tempat tinggal dan sisanya terjadi di hotel/restaurant, kantor, dan lainnya masing-masing sebesar $4 \%$, $5 \%, 8 \%$ ). Sedangkan berdasarkan tempat kejadian KLB tertinggi terjadi pada anak-anak di sekolah dasar (SD) yaitu 19 kejadian dengan jumlah korban sakit sebanyak 575 orang (BPOM RI, 2002).

Pada tahun 2015 data kejadian luar biasa (KLB), jenis pangan penyebab KLB Keracunan pangan tahun 2015 adalah masakan rumah tangga sebanyak 25 kejadian (40,98\%), pangan jajanan sebanyak 14 kejadian $(22,95 \%)$, pangan jasa boga sebanyak 13 kejadian $(21,31 \%)$, dan pangan olahan sebanyak 9 kejadian $(14,75 \%)$ (BPOM RI, 2016).
Hasil studi pendahuluan yang dilaksanakan melalui observasi ke lokasi, masih banyak ditemukan pedagang makanan yang kurang memperhatikan kebersihan makanannya dan berperilaku tidak sehat pada saat menjamah makanannya, seperti tidak mencuci tangan sebelum mengolah makanan, merokok sampai menggaruk anggota tubuh. Di samping itu juga terdapat yang kurang memperhatikan hygiene sanitasi seperti kebersihan kuku dan tangan, air pencucian dan kain lap yang digunakan berulang kali, tempat menyimpan makanan yang tidak ditutup. Selain itu pedagang juga cenderung berjualan di lokasi yang memungkinkan terjadinya kontaminasi pada makanan, seperti tempat berjualan yang terlalu dekat dengan jalan yang dapat menyebabkan makanan terpapar debu dan asap kendaraan bermotor. Dari uraian kondisi tersebut maka sangat memungkinkan makanan terkontaminasi bakteri patogen, sehingga makanan tersebut dapat menjadi sumber penyakit bagi yang mengkonsumsinya.

Tujuan penelitian untuk mengukur hubungan hygiene sanitasi dan perilaku penjamah dengan angka kuman pada makanan jajanan di lingkungan sekolah Yayasan Kartika Jaya Kota Bandar Lampung.

\section{METODE}

Penelitian yang digunakan adalah deskriptif analitik dengan rancangan cross sectional. Penelitian ini dilaksanakan di lingkungan sekolah Yayasan Kartika Jaya Kota Bandar Lampung yaitu di Jalan Kapt. Tendean, Jalan Pagar Alam, Jalan Imam Bonjol dan Jalan Nusa Indah. Sedangkan untuk pemeriksaan bakteriologis (angka kuman) makanan jajanan dilakukan di Laboratorium Jurusan Kesehatan Lingkungan. Berdasarkan kriteria sampel makanan, maka makanan yang akan diambil untuk sampel adalah 53 jenis makanan dari 53 pedagang.

Pengumpulan Data dilakukan dengan menggunakan kuisioner dilakukan kepada penjual jajanan untuk mengetahui perilaku penjamah makanan, Observasi melakukan pengamatan secara langsung untuk mengetahui kelayakan sanitasi tempat berjualan, sanitasi peralatan, penyimpanan bahan makanan, dan penyajian makanan. Serta untuk melihat hygiene personal pedagang makanan yang meliputi kebersihan tangan dan kuku, kebersihan rambut, dan kebersihan pakaian dan Pemeriksaan bakteriologis (angka kuman). Data-data yang 
diperoleh kemudian dianalisa secara univariat dan bivariat.

Penelitian ini telah melewati kaji etik dan mendapatkan Ethical Clearance dengan Nomor 021/EC/KEP-TJK/VII/2016 dari Komisi Etik Penelitian Kesehatan Politeknik Kesehatan Tanjung Karang.

\section{HASIL}

Hygiene sanitasi merupakan hasil pengelompokan dari hygiene personal pedagang dan sanitasi makanan. Hasil mengenai variabel hygiene sanitasi dapat dilihat pada Tabel 1.

Tabel 1. Distribusi Frekuensi Hygiene Sanitasi, Hygiene Personal Pedagang, Tindakan Penjamah, Pengetahuan Penjamah dan Angka Kuman pada Sampel Makanan Jajanan

\begin{tabular}{|c|c|c|}
\hline Variabel & Frekuensi & $\%$ \\
\hline \multicolumn{3}{|l|}{ Hygiene Sanitasi } \\
\hline Buruk & 17 & 32,1 \\
\hline Baik & 36 & 67,9 \\
\hline \multicolumn{3}{|c|}{ Hygiene Personal Pedagang } \\
\hline Buruk & 19 & 35,8 \\
\hline Baik & 34 & 64,2 \\
\hline \multicolumn{3}{|l|}{ Sanitasi Makanan } \\
\hline Buruk & 11 & 20,8 \\
\hline Baik & 42 & 79,2 \\
\hline \multicolumn{3}{|c|}{ Perilaku penjamah makanan } \\
\hline Buruk & 25 & 47,2 \\
\hline Baik & 28 & 52,8 \\
\hline \multicolumn{3}{|c|}{ Tindakan penjamah makanan } \\
\hline Buruk & 10 & 18,9 \\
\hline Baik & 43 & 81,1 \\
\hline \multicolumn{3}{|l|}{ Pengetahuan } \\
\hline Buruk & 27 & 51 \\
\hline Baik & 26 & 49 \\
\hline \multicolumn{3}{|l|}{ Angka kuman } \\
\hline \multirow{2}{*}{$\begin{array}{l}\text { Memenuhi syarat } \\
\text { Tidak memenuhi } \\
\text { syarat }\end{array}$} & 43 & 81,1 \\
\hline & 10 & 18,9 \\
\hline
\end{tabular}

Berdasarkan tabel 1, sebanyak $32,1 \%$ memiliki hygiene sanitasi yang buruk dan $67,9 \%$ memiliki hygiene sanitasi yang baik.

Pada variabel hygiene sanitasi terdapat dua komponen yaitu hygiene personal pedagang dan sanitasi makanan.

1). Hygiene personal pedagang

Hygiene personal pedagang yang dimaksud adalah bagaimana sikap bersih perilaku penjamah makanan agar makanan tidak tercemar, beberapa hal yang diperhatikan pada hygiene personal pedagang meliputi kebersihan tangan dan kuku, kebersihan rambut, serta kebersihan pakaian. Pada item kebersihan tangan dan kuku dilakukan pemeriksaan usap tangan penjamah sebagai parameter kebersihan tangan dan kuku.

Berdasarkan tabel 1, sebanyak 64,2\% memiliki hygiene personal pedagang yang sudah baik dan namun masih terdapat $35,8 \%$ memiliki hygiene personal pedagang yang buruk.

\section{2). Sanitasi Makanan}

Sanitasi makanan yang dimaksud adalah suatu tindakan untuk memelihara dan melindungi kebersihan lingkungan dari subyeknya yaitu makanan, seperti sanitasi tempat berjualan, sanitasi alat, penyimpanan bahan makanan, dan penyajian makanan.

Berdasarkan tabel 1, sebagian besar sudah memiliki sanitasi makanan yang baik yaitu sebanyak $79,2 \%$. Namun masih terdapat $20,8 \%$ dengan sanitasi makanan yang buruk.

\section{Perilaku Penjamah Makanan}

Perilaku penjamah merupakan hasil pengelompokan dari tindakan dan pengetahuan penjamah. Perilaku penjamah dikatakan "baik" apabila tindakan dan pengetahuan baik. Sedangkan dikatakan buruk apabila salah satu dan keduanya buruk.

Berdasarkan tabel 1 terdapat $52,8 \%$ sudah memiliki perilaku yang baik namun masih terdapat $47,2 \%$ memiliki perilaku yang buruk. Perilaku penjamah meliputi dua komponen yaitu tindakan dan pengetahuan penjamah.

\section{Tindakan Penjamah}

Tindakan penjamah yang dimaksud yaitu perilaku yang ditujukan penjamah, seperti kebiasaan yang sering dilakukan saat menjamah makanan. Sedangkan pengetahuan penjamah adalah seberapa jauh kemampuan dalam mengetahui mengenai hygiene sanitasi.

Berdasarkan tabel 1 terdapat $81,9 \%$ memiliki tindakan saat menjamah yang baik namun masih terdapat $18,9 \%$ memiliki tindakan saat menjamah yang buruk.

\section{Pengetahuan Penjamah}

Pengetahuan penjamah yang dimaksud adalah kemampuan penjamah dalam mengetahui hygiene sanitasi makanan serta bagaimana tindakan yang harus diketahui oleh penjamah makanan

Berdasarkan tabel 1 terdapat 51\% memiliki pengetahuan yang buruk, dan $49 \%$ memiliki pengetahuan yang baik.

Hasil penelitian yang dilakukan terhadap 53 sampel makanan jajanan, diperoleh hasil bahwa sebagian besar sampel memenuhi syarat 
yaitu sebanyak $81,1 \%$, namun masih terdapat pula sampel makanan dengan angka kuman yang tidak memenuhi syarat sebanyak $18,9 \%$. Sedangkan berdasarkan jenis makanannya, makanan yang tidak memenuhi syarat antara lain sate telur, cimol, pempek panggang, batagor, cilok, tahu bulat, somay, dan pecel.

\section{Hubungan Hygiene Sanitasi dengan Angka Kuman Pada Makanan Jajanan}

Tabel 2. Hubungan Hygiene Sanitasi dan Angka Kuman pada Makanan Jajanan

\begin{tabular}{|c|c|c|c|c|c|c|}
\hline \multirow{3}{*}{$\begin{array}{c}\text { Hygiene personal } \\
\text { pedagang }\end{array}$} & \multicolumn{4}{|c|}{ Angka kuman pada makanan } & \multirow{3}{*}{ p-value } & \multirow{3}{*}{ OR $95 \%$ CI } \\
\hline & \multicolumn{2}{|c|}{$\begin{array}{c}\text { Tidak memenuhi } \\
\text { syarat }\end{array}$} & \multicolumn{2}{|c|}{$\begin{array}{l}\text { Memenuhi } \\
\text { syarat }\end{array}$} & & \\
\hline & $\mathbf{n}$ & $\%$ & $\mathbf{n}$ & $\%$ & & \\
\hline Buruk & 9 & 52,9 & 8 & 47,1 & & \\
\hline Baik & 1 & 2,8 & 35 & 97,2 & 0,0001 & $\begin{array}{r}39,375 \\
4525624\end{array}$ \\
\hline Total & 10 & 18,9 & 43 & 81,1 & & $(4,345-356,834)$ \\
\hline
\end{tabular}

Dari tabel 2, diketahui hasil uji statistik menggunakan Chi-Square diperoleh p-value $0,0001<0,05$ yang berarti Ho ditolak sehingga dapat disimpulkan terdapat hubungan antara hygiene sanitasi dengan angka kuman pada makanan jajanan. Nilai Odd Ratio $(\mathrm{OR})=39,375$ $(95 \% \mathrm{CI}=4,345-356,834)$, menunjukkan responden dengan hygiene sanitasi pedagang yang buruk mempunyai resiko 39,375 kali lebih besar menyebabkan makanan jajanannya tidak memenuhi syarat.

Sedangkan berdasarkan hubungan komponen hygiene sanitasi yaitu hygiene personal pedagang dan sanitasi dengan angka kuman pada makanan jajanan dapat dilihat pada uraian dibawah ini.

\section{Hubungan Hygiene Personal Pedagang dengan Angka Kuman pada Makanan Jajanan}

Tabel 3. Hubungan Hygiene Personal Pedagang dan Angka Kuman pada Makanan Jajanan

\begin{tabular}{|c|c|c|c|c|c|c|}
\hline \multirow{3}{*}{$\begin{array}{l}\text { Hygiene personal } \\
\text { pedagang }\end{array}$} & \multicolumn{4}{|c|}{ Angka kuman pada makanan } & \multirow{3}{*}{ p-value } & \multirow{3}{*}{ OR 95\% CI } \\
\hline & \multicolumn{2}{|c|}{$\begin{array}{c}\text { Tidak memenuhi } \\
\text { syarat }\end{array}$} & \multicolumn{2}{|c|}{$\begin{array}{l}\text { Memenuhi } \\
\text { syarat }\end{array}$} & & \\
\hline & $\mathbf{n}$ & $\%$ & $\mathbf{n}$ & $\%$ & & \\
\hline Buruk & 9 & 47,4 & 10 & 52,6 & & \\
\hline Baik & 1 & 2,9 & 33 & 97,1 & 0,0001 & $\begin{array}{r}29,700 \\
2627072-15\end{array}$ \\
\hline Total & 10 & 18,9 & 43 & 81,1 & & \\
\hline
\end{tabular}

Dari tabel 3, diketahui hasil uji statistik menggunakan Chi-Square diperoleh p-value 0,0001 $(\mathrm{OR}=29,700 ; 95 \% \mathrm{CI}=3,345-263,727)<0,05$ yang berarti Ho ditolak sehingga dapat disimpulkan terdapat hubungan antara hygiene personal pedagang dengan angka kuman pada makanan jajanan di lingkungan Sekolah Yayasan Kartika Jaya Kota Bandar Lampung.

\section{Hubungan Sanitasi Makanan dengan Angka Kuman pada Makanan Jajanan}

Tabel 4. Hubungan Sanitasi Makanan dan Angka Kuman pada Makanan Jajanan

\begin{tabular}{|c|c|c|c|c|c|c|}
\hline \multirow{3}{*}{$\begin{array}{c}\text { Sanitasi } \\
\text { Makanan }\end{array}$} & \multicolumn{4}{|c|}{ Angka kuman pada makanan } & \multirow{3}{*}{ p-value } & \multirow{3}{*}{ OR 95\% CI } \\
\hline & \multicolumn{2}{|c|}{$\begin{array}{c}\text { Tidak memenuhi } \\
\text { syarat }\end{array}$} & \multicolumn{2}{|c|}{$\begin{array}{l}\text { Memenuhi } \\
\text { syarat }\end{array}$} & & \\
\hline & $\mathbf{n}$ & $\%$ & $\mathbf{n}$ & $\%$ & & \\
\hline Buruk & 6 & 54,5 & 5 & 45,5 & & \\
\hline Baik & 4 & 9,5 & 38 & 90,5 & 0,003 & $\begin{array}{r}11,400 \\
368-54885)\end{array}$ \\
\hline Total & 10 & 18,9 & 43 & 81,1 & & \\
\hline
\end{tabular}

Secara statistik dengan menggunakan uji Chi-Square hasil perhitungan diatas menunjukan $p$-value $0,003 \quad(\mathrm{OR}=11,400 ; \quad 95 \% \mathrm{CI}=2,368$ $54,885)<0,05$ yang berarti Ho ditolak sehingga menunjukan bahwa ada hubungan antara sanitasi makanan dengan angka kuman pada makanan jajanan di lingkungan Sekolah Yayasan Kartika Jaya Kota Bandar Lampung. 


\section{Hubungan Perilaku Penjamah dengan Angka Kuman Pada Makanan Jajanan}

Tabel 5. Hubungan Perilaku Penjamah Makanan dengan Angka Kuman pada Makanan Jajanan

\begin{tabular}{|c|c|c|c|c|c|c|}
\hline \multirow{3}{*}{$\begin{array}{c}\text { Perilaku penjamah } \\
\text { makanan }\end{array}$} & \multicolumn{4}{|c|}{ Angka kuman pada makanan } & \multirow{3}{*}{ p-value } & \multirow{3}{*}{$\begin{array}{c}\text { OR } \\
95 \% \mathrm{CI}\end{array}$} \\
\hline & \multicolumn{2}{|c|}{$\begin{array}{c}\text { Tidak memenuhi } \\
\text { syarat }\end{array}$} & \multicolumn{2}{|c|}{ Memenuhi syarat } & & \\
\hline & n & $\%$ & $\mathbf{n}$ & $\%$ & & \\
\hline Buruk & 9 & 36 & 16 & 64 & \multirow{3}{*}{0,004} & \multirow{3}{*}{$\begin{array}{r}15,188 \\
(1,758-131,238)\end{array}$} \\
\hline Baik & 1 & 3,6 & 27 & 96,4 & & \\
\hline Total & 10 & 18,9 & 43 & 81,1 & & \\
\hline
\end{tabular}

Hasil analisis uji statistik dengan menggunakan uji Chi Square diperoleh P-Value $0,004 \quad(\mathrm{OR}=15,188 ; \quad 95 \% \quad \mathrm{CI}=1,758$ $131,238)<0,05$ yang berarti Ho ditolak, sehingga disimpulkan ada hubungan antara perilaku penjamah dengan angka kuman pada makanan jajanan di lingkungan Sekolah Yayasan Kartika Jaya Kota Bandar Lampung. Nilai Odd Ratio $(\mathrm{OR})=15,188$;

$(95 \% \mathrm{CI}=1,758-131,238)$, menunjukkan responden dengan perilaku yang buruk mempunyai resiko 15,188 kali lebih besar menyebabkan makanan jajanannya tidak memenuhi syarat.

Sedangkan berdasarkan hubungan komponen perilaku penjamah makanan yaitu tindakan dan pengetahuan penjamah dengan angka kuman pada makanan jajanan dapat dilihat pada uraian dibawah ini.

\section{Tindakan Penjamah Makanan}

Tabel 6. Hubungan Tindakan Penjamah Makanan Dengan Angka Kuman pada Makanan Jajanan

\begin{tabular}{|c|c|c|c|c|c|c|}
\hline \multirow{3}{*}{$\begin{array}{c}\text { Tindakan penjamah } \\
\text { makanan }\end{array}$} & \multicolumn{4}{|c|}{ Angka kuman pada makanan } & \multirow{3}{*}{ p-value } & \multirow{3}{*}{ OR $95 \%$ CI } \\
\hline & \multicolumn{2}{|c|}{$\begin{array}{c}\text { Tidak memenuhi } \\
\text { syarat }\end{array}$} & \multicolumn{2}{|c|}{$\begin{array}{c}\text { Memenuhi } \\
\text { syarat }\end{array}$} & & \\
\hline & $\mathbf{n}$ & $\%$ & $\mathbf{n}$ & $\%$ & & \\
\hline Buruk & 5 & 50 & 5 & 50 & \multirow{3}{*}{0,014} & \multirow{3}{*}{$\begin{array}{r}7,600 \\
(1,611-35,847)\end{array}$} \\
\hline Baik & 5 & 11,6 & 38 & 88,4 & & \\
\hline Total & 10 & 18,9 & 43 & 81,1 & & \\
\hline
\end{tabular}

Hasil analisis uji statistik dengan menggunakan uji Chi Square diperoleh $p$-value $0,014 \quad(\mathrm{OR}=7,600 ; 95 \% \mathrm{CI}=1,611-35,847)<0,05$ yang berarti Ho ditolak, sehingga disimpulkan ada hubungan antara tindakan penjamah makanan dengan angka kuman pada makanan jajanan di lingkungan Sekolah Yayasan Kartika Jaya Kota Bandar Lampung.

\section{Pengetahuan Penjamah Makanan}

Tabel 7. Hubungan Pengetahuan Penjamah Makanan dan Angka Kuman pada Makanan Jajanan

\begin{tabular}{|c|c|c|c|c|c|c|}
\hline \multirow{3}{*}{$\begin{array}{c}\text { Pengetahuan } \\
\text { Penjamah Makanan }\end{array}$} & \multicolumn{4}{|c|}{ Angka kuman pada makanan } & \multirow{3}{*}{ P-Value } & \multirow{3}{*}{ OR $95 \% C I$} \\
\hline & \multicolumn{2}{|c|}{$\begin{array}{c}\text { Tidak memenuhi } \\
\text { syarat }\end{array}$} & \multicolumn{2}{|c|}{$\begin{array}{c}\text { Memenuhi } \\
\text { syarat }\end{array}$} & & \\
\hline & $\mathbf{n}$ & $\%$ & $\mathbf{n}$ & $\%$ & & \\
\hline Buruk & 9 & 33,3 & 18 & 66,7 & \multirow{3}{*}{0.011} & \multirow{3}{*}{$\begin{array}{r}12,500 \\
(1,452-107,632)\end{array}$} \\
\hline Baik & 1 & 3,8 & 25 & 96,2 & & \\
\hline Total & 10 & 18,9 & 43 & 81,1 & & \\
\hline
\end{tabular}

Berdasarkan hasil analisis uji statistik dengan menggunakan uji Chi Square diperoleh $p$ value $0,011 \quad(\mathrm{OR}=12,500 ; \quad 95 \% \mathrm{CI}=1,452$ $107,632)<0,05$ yang berarti Ho ditolak sehingga dapat disimpulkan ada hubungan antara pengetahuan pedagang dengan angka kuman pada makanan jajanan di lingkungan Sekolah Yayasan Kartika Jaya Kota Bandar Lampung. 


\section{PEMBAHASAN}

\section{Angka Kuman pada Makanan Jajanan}

Pemeriksaan angka kuman pada makanan jajanan dilakukan dengan menggunakan metode Angka Lempeng Total (ALT) atau Total Plate Count (TPC) yaitu dengan penghitungan koloni yang dilaporkan sebagai Standard Plate Count (SPC). Hasil pemeriksaan yang telah dilakukan di laboratorium diketahui bahwa hampir sebagian besar yaitu sebanyak 43 makanan jajanan $(81,1 \%)$ dinyatakan memenuhi syarat karena tidak melebihi batas maksimum yang ditetapkan dalam Peraturan Kepala BPOM No.16 Tahun 2016 sesuai dengan jenis makanannya. Namun masih terdapat 10 makanan jajanan $(18,9 \%)$ yang tidak memenuhi syarat. Sedangkan berdasarkan jenis makanannya, makanan yang termasuk dalam kelompok angka kuman tidak memenuhi syarat yaitu antara lain sate telur, cimol, bakso tusuk, seafood, pempek panggang, batagor, cilok, tahu bulat, sate obong, bakso bakar, seafood bakar, sate lobster, somay, pecel dan mi goreng. Pertumbuhan bakteri pada pangan dipengaruhi oleh berbagai faktor dan setiap jenis bakteri membutuhkan kondisi pertumbuhan yang berbeda. Oleh karena itu, jenis dan jumlah mikroba yang dapat tumbuh kemudian menjadi dominan pada pangan juga berbeda. Terdapatnya angka kuman pada makanan jajanan juga dipengaruhi oleh beberapa faktor seperti hygiene sanitasi yang buruk sebanyak 31 responden $(58,5 \%)$ dan perilaku penjamah yang buruk sebanyak 25 responden $(47,2 \%)$.

Angka kuman pada makanan jajanan sebagian besar diakibatkan karena pedagang tidak menerapkan persyaratan hygiene sanitasi yang baik dan benar. Keadaan hygiene sanitasi yang buruk mempengaruhi kualitas makanan yang disajikan kepada konsumen. Hal ini jelas akan berpengaruh juga terhadap tingkat kesehatan konsumen yang mengkonsumsi makanan tersebut. Jika hygiene sanitasi makanannya buruk maka dapat mengakibatkan timbulnya masalah-masalah kesehatan seperti foodborne disease dan kasus keracunan makanan.

Kualitas makanan dipengaruhi oleh berbagai faktor, mulai dari faktor makanan, manusia dan peralatan. Pemilihan bahan makanan sampai dengan penyajian makanan serta penjamah makanan dan peralatan yang digunakan semua nya harus memenuhi persyaratan.

Hygiene perorangan akan terlibat dalam pengolahan makanan apabila dalam diri pekerja tertanam pengertian tentang pentingnya menjaga kesehatan dan kebersihan diri. Hygiene sanitasi makanan dapat mempengaruhi kualitas makanan yang diolahnya. Syarat utama pengolah makanan adalah memiliki kesehatan yang baik. Karena jika personal hygiene penjamah buruk dapat menyebabkan adanya kontaminasi kuman.

\section{Hubungan Hygiene Sanitasi dengan Angka Kuman}

Hasil penelitian yang dilakukan terhadap 53 responden menunjukan bahwa sebanyak 58,5\% memiliki hygiene sanitasi yang buruk dan 41,5\% memiliki hygiene sanitasi yang baik. Sedangkan hasil Uji chi-square diperoleh $p$-value kurang dari alpha $(0,033<0,05)$, maka dapat disimpulkan ada hubungan antara hygiene sanitasi dengan angka kuman pada makanan jajanan di lingkungan Sekolah Yayasan Kartika Jaya Kota Bandar Lampung.

Faktor penyebab dari hygiene sanitasi yang buruk antara lain dipengaruhi oleh hygiene personal pedagang dan sanitasi makanan, berdasarkan hasil uji statistik menggunakan Chi square diperoleh $p$-value kurang dari alpha, hal tersebut menunjukan bahwa ada hubungan pada komponen hygiene personal pedagang $(0,0001<0,05)$ dan sanitasi makanan $(0,003<0,05)$ dengan angka kuman pada makanan jajanan. Sedangkan berdasarkan komponen yang paling dominan dalam mempengaruhi hygiene sanitasi adalah faktor hygiene personal pedagang $(\mathrm{OR}=29,700 ; 95 \% \mathrm{CI}=3,345-263,727)$. Indikator kebersihan tangan dan kuku merupakan salah satu penyebab dari hygiene personal pedagang yang buruk. Dari hasil pengamatan banyak ditemui pedagang yang tidak mencuci tangannya menggunakan sabun dan air bersih yang mengalir, pedagang hanya mencuci tangan dengan air yang ada di ember biasa serta didapati beberapa pedagang hanya menggunakan kain lap untuk membersihkan kotoran ditangan bahkan ditemukan pula pedagang yang sama sekali tidak mencuci tangannya. Kondisi tersebut dapat menyebabkan kontaminasi pada makanan dimana keadaan tangan dan kuku yang kotor atau terkontaminasi dapat 
memindahkan bakteri dan virus patogen dari tubuh, feses, atau sumber lain dari makanan. Menurut penelitian Lambrechts dkk (2014) dalam naskah publikasi Romanda (2017) Tangan penjamah makanan terbukti merupakan vektor penyebaran penyakit bawaan makanan. Bahwa tangan manusia merupakan sumber utama mikroorganisme, jika kontak langsung dengan tangan selama produksi, pengolahan dan penyajian maka terjadilah perpindahan mikroba dari tangan ke pangan. Tangan dan kuku-kuku yang panjang juga dapat menjadi tempat berkembangbiaknya bakteri patogen terutama golongan mesofilik seperti Bacillus, Clostridium, Pseudomonas, Micrococcus dan Proteus. Dimana bakteri-bakteri tersebut tentunya akan dapat mencemari makanan jajanan pada saat pengolahan yang dilakukan oleh pedagang sehingga dapat mengakibatkan tingginya jumlah kuman pada makanan. Hal ini sangat diperkuat bila higiene perorangan tidak bersih dan tidak berperilaku yang baik dalam mengolah makanan maka dapat menimbulkan kontaminasi terhadap makanan.

Faktor lain yang juga menyebabkan hygiene personal yang buruk adalah pedagang tidak memakai penutup rambut. Beberapa pedagang membiarkan rambutnya terurai atau dibiarkan terbuka. Hal ini bisa mengakibatkan kontaminasi silang apabila rambut dibiarkan dalam proses memasak. Menurut Fathonah (2005) pada saat bekerja pedagang diharuskan menggunakan penutup kepala atau rambut. Penutup kepala membantu mencegah rambut masuk ke makanan, membantu menyerap keringat yang ada di dahi, mencegah kontaminasi bakteri staphylococci, serta menjaga rambut bebas dari kotoran.

Sedangkan untuk kebersihan pakaian sebagian besar dari mereka sudah menggunakan pakaian yang bersih sebagaimana yang disebutkan oleh Fathonah (2005), pakaian yang digunakan harus selalu bersih, pakaian seharusnya adalah pakaian yang berlengan, menutupi bahu dan ketiak pekerja.

Menurut Agustina sumber kontaminasi makanan yang paling utama salah satunya berasal dari pekerja atau pengolah makanan, peralatan, sampah, serangga, tikus, dan faktor lingkungan seperti udara dan air. Dari seluruh sumber kontaminasi makanan tersebut pekerja adalah paling besar pengaruh kontaminasinya. Kesehatan dan kebersihan pengolah makanan mempunyai pengaruh yang cukup besar pada mutu produk yang dihasilkannya, sehingga perlu mendapatkan perhatian yang sungguh-sungguh (Wahyuni, 2016).

Sedangkan pengamatan dari segi sanitasi, tidak layaknya tempat penyimpanan makanan menjadi salah satu faktor yang mempengaruhi sanitasi makanan menjadi buruk. Seperti pada beberapa pedagang yang ditemui, mereka hanya menutup makanan dengan penutup seadanya seperti menutup dengan menggunakan koran, penggunaan tirai makanan yang berlubang serta kaca yang hanya menutup bagian depannya saja, hal tersebut tentunya dapat memungkinkan lalat masuk dan hinggap pada makanan. Serta pada pedagang lainnya ditemukan kondisi tempat penyimpanan makanannya yang dibiarkan terbuka, padahal makanan dalam keadaan terbuka akan menyebabkan makanan terkotaminasi mikroorganisme ataupun senyawa berbahaya lainnya. Tempat penyimpanan makanan yang baik seharusnya di tempat atau wadah yang bersih, tidak berdebu, tempat penyimpanan memiliki penutup, serta dapat terhindar dari sumber kontaminasi. Faktor lain yang dapat menyebabkan sanitasi makanan yang buruk adalah lokasi tempat berjualan yang terlalu dekat dari sumber pencemaran seperti terlalu dekat dengan jalan raya sehingga makanan menjadi rentan terkontaminasi oleh asap kendaraan dan debu. Lokasi tempat berjualan yang terlalu dekat dengan tempat pembuangan sampah juga dapat menyebabkan sanitasi makanan menjadi buruk karena lokasi tempat berjualan yang kotor dapat menjadi sarang serangga dan binatang pengganggu. Sebagaimana yang terdapat pada Keputusan Menteri Kesehatan RI No. 942/Menkes/SK/VII/2003 Tentang Pedoman Persyaratan Hygiene Sanitasi Makanan Jajanan bahwa lokasi berjualan harus cukup jauh dari sumber pencemaran atau dapat menimbulkan pencemaran makanan jajanan seperti pembuangan sampah terbuka, tempat pengolahan limbah, rumah potong hewan, jalan yang ramai dengan arus kecepatan tinggi.

Hal lainnya yang juga mempengaruhi sanitasi menjadi buruk yaitu penggunaan peralatan makan/masak, masih banyak dijumpai pedagang yang tidak menggunakan alat penjepit makanan, padahal penggunaan alat penjepit makanan berfungsi untuk menghindari kontaminasi pada makanan, karena menyentuh makanan langsung dengan tangan dapat mempengaruhi sanitasi 
makanan. Kondisi peralatan yang kotor atau pun tidak layak digunakan dapat menjadi sumber kontaminasi bagi makanan. peralatan makan yang baik seharusnya tidak boleh patah, tidak mudah berkarat, penyok, tergores atau retak, karena akan menjadi sarang kotoran atau bakteri. Serta peralatan yang tidak utuh tidak mungkin dapat dicuci sempurna sehingga dapat menjadi sumber kontaminasi. Pencucian alat makan/masak dengan air yang digunakan berulang juga beresiko menyebabkan makanan terkontaminasi oleh kuman dan bakteri. menjadi buruk.

Pada saat penyajian, kebanyakan pedagang menggunakan bungkus berupa plastik, kertas, ataupun kotak plastik. Namun ditemukan pada beberapa pedagang yang menggunakan kotak sterofoam, padahal jenis wadah tersebut tidak baik dan tidak aman untuk membungkus makanan karena penggunaan wadah tersebut efek jangka panjangnya dapat menyebabkan gangguan kesehatan pada manusia. Menurut Kusmayadi (2007), penggunaan pembungkus seperti plastik, kertas atau box plastik harus dalam keadaan bersih dan tidak berasal dari bahan-bahan yang dapat menimbulkan racun.

Untuk menghindari berbagai penyakit akibat kontaminasi pada makanan, perlu dilakukan upaya pencegahan. Pencegahan harus dimulai dari menjaga kebersihan diri sendiri sebelum beraktifitas atau sebelum menyiapkan makanan hingga meningkatkan sanitasi makanan. Maka dari itu diharapkan pedagang dapat meningkatkan hygiene sanitasi, seperti menjaga kebersihan kuku dan tangan, mencuci tangan sebelum dan sesudah menjamah makanan dengan menggunakan sabun dan air yang mengalir, memakai penutup kepala dan mengikat rambut, serta diharapakan pula bagi pedagang dapat memperbaiki tempat penyimpanan makanannya, seperti memberikan tutup yang layak yang dapat melindungi makanan dari serangga/binatang pengganggu serta debu dan asap kendaraan. serta selalu mengganti air pada bak pencucian guna mengurangi kontaminasi makanan.

\section{Perilaku Penjamah Makanan}

Berdasarkan hasil penelitian, didapatkan 25 responden $(47,2 \%)$ memiliki perilaku penjamah yang buruk dan 28 responden $(52,8 \%)$ memiliki perilaku yang baik. Perilaku penjamah yang buruk ditujukan oleh tindakan dan pengetahuan penjamah. berdasarkan hasil uji statistik menggunakan Chi square diperoleh $p$-value kurang dari alpha, hal tersebut menunjukan bahwa ada hubungan pada komponen tindakan penjamah $(0,014<0,05)$ dan pengetahuan penjamah $(0,011<0,05)$ dengan angka kuman pada makanan jajanan. Pada variabel perilaku, tingkat pengetahuan penjamah merupakan komponen yang paling dominan untuk menyebabkan perilaku penjamah menjadi buruk (OR=15,188; 95\% CI=1,758-131,238). Tindakan yang buruk seperti kebiasaan mencuci tangan, masih banyak ditemui pedagang yang tidak mencuci tangan dengan benar, pedagang hanya mencuci tangan pada ember atau hanya menggunakan kain lap bahkan ada yang tidak mencuci tangannya sebelum menjamah makanan. Minimnya sarana untuk mencuci tangan menyebabkan mereka malas atau tidak sempat untuk mencuci tangan. Pada saat observasi dilakukan, banyak pedagang yang menyentuh anggota tubuh, tidak menutup mulut saat bersin dan mengobrol sewaktu mengolah makanan juga merupakan salah satu tindakan yang buruk, karena patogen atau mikroorganisme di udara dapat terbawa oleh partikel-partikel debu, air, atau titik-titik ludah yang disebarkan oleh dan dapat masuk kedalam makanan.

Pada dasarnya tindakan penjamah makanan sebagian besar sudah baik. Namun masih ada halhal yang sering dilakukan dalam penanganan makanan yaitu masih seringnya menyentuh atau menggaruk anggota tubuh pada saat mengolah makanan dan tidak menutup mulut atau hidung saat batuk bersin, serta kebiasaan mencuci tangan yang masih rendah.

Pedagang makanan umumnya tidak mengetahui bagaimana cara mencuci tangan yang benar, mereka hanya mengetahui mencuci tangan cukup dibilas air dan sabun, padahal disebutkan Fathonah (2005) pencucian tangan yang memadai untuk menjamin kebersihan adalah membasahi tangan dengan air yang mengalir dengan menggunakan sabun serta menggosokkan tangan, sela-sela jari dan kuku serta dikeringkan dengan handuk bersih atau tissue.

Sedangkan untuk pengetahuan penjamah, masih banyak dari pedagang belum mengetahui mengenai hygiene sanitasi serta tindakan dalam menjamah makanan, seperti tidak mengetahui kebiasaan hidup yang seharusnya tidak dilakukan saat mengolah makanan, seperti tidak merokok, 
mencicipi makanan atau mengunyah, menutup mulut atau hidung saat bersin, serta tidak menggaruk anggota tubuh saat sedang menjamah makanan. Beberapa responden belum mengetahui tindakan yang dapat menyebabkan makanan tercemar, serta belum mengetahui bagaimana seharusnya tempat penyimpanan makanan yang baik. Kurangnya pengetahuan mengenai menjaga hygiene personal juga menjadi salah satu yang menyebabkan pengetahuan penjamah buruk.

Salah satu keterbatasan dalam penelitian ini adalah tidak adanya data tingkat pendidikan responden sehingga peneliti tidak dapat menganalisis hubungan pengetahuan dengan tingkat pendidikan, padahal dimungkinkan bahwa rendahnya kualitas makanan jajanan berkaitan dengan rendahnya tingkat pendidikan dan pengetahuan dari penjamah makanan yang menanganinya. Maka diharapkan bagi peneliti selanjutnya, perlu dilakukan penelitian lanjutan untuk melihat variabel-variabel yang belum diteliti dalam penelitian ini, sehingga data pendukung yang diperoleh akan lengkap.

Hasil uji chi-square hubungan antara perilaku penjamah dengan angka kuman pada makanan jajanan diperoleh $p$-value $0,004<0,05$, yang berarti terdapat hubungan antara perilaku penjamah dengan angka kuman pada makanan jajanan di lingkungan Sekolah Yayasan Kartika Jaya Kota Bandar Lampung. Hal yang sama juga disebutkan pada penelitian yang dilakukan oleh Wibawa (2006) dalam skripsi Sofiana (2012) menyatakan bahwa perilaku penjamah makanan berhubungan secara bermakna dengan kontaminasi bakteriologis pada makanan jajanan di Sekolah Dasar Tangerang. Disebutkan pula oleh

\section{DAFTAR PUSTAKA}

BPOM RI. (2002). Materi Penyuluhan Keamanan Pangan Bagi Penyuluh Kemanan Pangan Industri Rumah Tangga. Jakarta.

BPOM RI. (2016). Laporan Tahunan Badan POM 2015. Jakarta.

Fathonah, S. (2005). Higiene dan Sanitasi Makanan. Buku Ilmiah. Semarang: Fakultas Teknik Universitas Negeri Semarang.

Februhartanty dan Rimbawan. (2004). Amankan Makanan Jajanan Anak Sekolah di Indonesia.
Kusmayadi (2008) bahwa perilaku seseorang penjamah memengaruhi kualitas makanan yang disajikan. Pada hasil penelitian Wibawa (2008) dalam skripsi Sofiana (2012) menunjukan pedagang dengan perilaku tidak baik berisiko 3,2 kali untuk terkontaminasi bakteri dibandingkan dengan pedagang dengan perilaku yang baik.

Maka dari itu perlu adanya kerjasama antara petugas kesehatan dari Puskesmas di wilayah Kecamatan Tanjungkarang Pusat dengan Kepala Sekolah dan UKS untuk melakukan kegiatan penyuluhan atau praktik langsung serta melakukan pengawasan kepada para pedagang makanan jajanan dilingkungan sekolah tersebut mengenai hygiene sanitasi makanan sehingga diharapkan dari kegiatan tersebut dapat meningkatan pengetahuan pedagang mengenai hygiene sanitasi serta perilaku bagi penjamah makanan.

\section{SIMPULAN}

Angka kuman pada makanan jajanan tidak memenuhi syarat. Ada hubungan antara hygiene sanitasi dengan angka kuman pada makanan jajanan di lingkungan Sekolah Yayasan Kartika Jaya Kota Bandar Lampung, sedangkan komponen yang paling dominan dalam hygiene sanitasi adalah hygiene personal pedagang.

Ada hubungan antara perilaku penjamah makanan dengan angka kuman pada makanan jajanan di lingkungan Sekolah Yayasan Kartika Jaya Kota Bandar Lampung, sedangkan komponen yang paling dominan dalam perilaku penjamah adalah pengetahuan penjamah.

http://www.gizi.net/cgibin/berita/fullnews.cg i?newsid1097726693,98302)

Keputusan Menteri Kesehatan Republik Indonesia. (2003). Nomor: 942/Menkes/SK/VII/2003

Tentang Persyaratan Hygiene Sanitasi Makanan Jajanan. Jakarta: Departemen Kesehatan Republik Indonesia Ditjen PPM \& PLP, Jakarta.

Kusmayadi, A., \& Sukandar, D. (2007). Cara Memilih dan Mengolah Makanan untuk Perbaikan Gizi Masyarakat. Special 
Programme For Food Security: Asia Indonesia, dari webmaster@ deptan.go.id.

Romanda, F., Priyambodo, P., \& Risanti, E. D. (2017). Hubungan Personal Hygiene Dengan Keberadaan Escherichia Coli Pada Makanan Di Tempat Pengolahan Makanan (TPM) Buffer Area Bandara Adi Soemarmo Surakarta. Biomedika, 8(1).

Sofiana, Erna. (2012). Hubungan Higiene dan Sanitasi dengan Kontaminasi Escherichia Coli pada Jajanan di Sekolah Dasar Kecamatan Tapos Depok. [Skripsi]. Depok: Program Studi Kesehatan Masyarakat, Fakultas Kesehatan Masyarakat, Universitas Indonesia.
Wahyuni, T. (2016). Hubungan Antara Hygiene dan Sanitasi Pengolahan Minuman Milkshake Powder Berbagai Rasa dengan Angka Kuman Yang dijajakan di sepanjang Jalan Kebonharjo Tanjung Mas Semarang. [Skripsi]. Semarang: Program Studi Kesehatan Masyarakat, Fakultas Kesehatan Masyarakat,Universitas Dian Nuswantoro.

World Health Organization. (2015). WHO's first ever global estimates of foodborne diseases find children under 5 account for almost one third of deaths. News release, Geneva, Switzerland. 